\title{
The effect of temperature on the efficiency of industrial wastewater nitrification and its (geno)toxicity
}

\author{
Anna Gnida, Jarosław Wiszniowski, Ewa Felis*, Jan Sikora, Joanna Surmacz-Górska, \\ Korneliusz Miksch
}

The Silesian University of Technology, Poland

Faculty of Energy and Environmental Engineering

Department of Environmental Biotechnology

*Corresponding author's e-mail: ewa.felis@polsı.pl

\begin{abstract}
Keywords: nitrification failure, activated sludge, industrial wastewater, high ammonium concentrations, (geno) toxicity.

Abstract: The paper deals with the problem of the determination of the effects of temperature on the efficiency of the nitrification process of industrial wastewater, as well as its toxicity to the test organisms. The study on nitrification efficiency was performed using wastewater from one of Polish chemical factories. The chemical factory produces nitrogen fertilizers and various chemicals. The investigated wastewater was taken from the influent to the industrial mechanical-biological wastewater treatment plant (WWTP). The WWTP guaranteed high removal efficiency of organic compounds defined as chemical oxygen demand (COD) but periodical failure of nitrification performance was noted in last years of the WWTP operation. The research aim was to establish the cause of recurring failures of nitrification process in the above mentioned WWTP. The tested wastewater was not acutely toxic to activated sludge microorganisms. However, the wastewater was genotoxic to activated sludge microorganisms and the genotoxicity was greater in winter than in spring time. Analysis of almost 3 years' period of the WWTP operation data and laboratory batch tests showed that activated sludge from the WWTP under study is very sensitive to temperature changes and the nitrification efficiency collapses rapidly under $16^{\circ} \mathrm{C}$. Additionally, it was calculated that in order to provide the stable nitrification, in winter period the sludge age (SRT) in the WWTP should be higher than 35 days.
\end{abstract}

\section{Introduction}

Production of nitrogen fertilizers is expanding rapidly resulting in high loads of (ionized und unionized) ammonia and nitrate discharged into the environment. The wastewater from fertilizer's production has a significant quantity of nitrogen in the ammonium and nitrate form, usually higher than $500 \mathrm{mg}$ $\mathrm{NH}_{4}-\mathrm{N} / \mathrm{L}$ (Wen et al. 2005). Such wastewater contains also a certain amount of chloride, nitrate, phosphate, silica and suspended matters. In Poland the fertilizer factories offer a variety of nitrogen products: mostly fertilizers, but also other chemicals as oxo-alcohols, urea reagents, pthalic anhydride (plasticizers) and maleic anhydride. These chemicals and other byproducts compose the resulting wastewater. Efficient biological nitrifying process is the most economic method for treating such effluents but performance of this process in full-scale systems is easily hindered by specific wastewater composition. The main problem during the treatment of this wastewater could be inhibition of ammonia oxidation at high concentrations of either substrate or product (Anthonisen et al. 1976, Vadivelu et al. 2007). Incomplete nitrification results in discharge of ammonium, ammonia and nitrite which are compounds toxic to the aquatic organisms and/or the main reason of eutrophication.
Due to specific wastewater composition the activated sludge microorganisms, responsible for the contaminants removal, can be more vulnerable to changeability of other crucial wastewater treatment parameters, such as temperature or dissolved oxygen concentration. On the other hand industrial wastewater is potential source of hazardous pollutants (including genotoxins), therefore, when they are discarded into the environment, they pose a potential threat to aquatic organisms as well as human health (OSPAR 2002).

The aim of the study was to determine the cause of the periodical nitrification failure in the WWTP treating fertilizer factory wastewater. Temperature and wastewater composition are known to be crucial factors that influence nitrification process. Taking into account that composition of the wastewater reported in this article is substantially different from typical composition of municipal wastewater and the nitrification failures occurred usually during winter period it was expected that the wastewater components may change the activated sludge sensitivity to temperature. Such a change would thus increase the minimal/optimal temperature for nitrification and increase required minimal sludge age. 


\section{Methods}

\section{Description of the WWTP under study}

The wastewater treatment plant (WWTP) under study receives mainly industrial wastewater from all departments of the chemical factory, namely: fertilizers and plasticizers production, production of oil additions (2 ethylhexanol, iso-butanolandn-butanol), cosmeticandpharmaceuticalproducts (iso-butyraldehyde, n-butyraldehyde, anhydrous ammonia, ammonia solution, sodium nitrate liquor, sodium nitrite, maleic anhydride, urea, technically pure urea crystal, octanol, technically pure urea liquor, compressed hydrogen) and sanitary wastewater. The wastewater reaches the secondary treatment part of the WWTP after primary treatment part which consists of primary clarifier, oil separator and equalizing tank. Table 1 shows the parameters of the raw wastewater (after primary treatment). The data cover a period of 735 operated days.

The secondary treatment comprises nitrification and denitrification processes carried out in the agitated activated sludge reactors. The average $\mathrm{COD}$ and $\mathrm{NH}_{4}-\mathrm{N}$ sludge loadings were 0.148 and $0.016 \mathrm{~g} / \mathrm{g}_{\mathrm{SS}} \cdot \mathrm{d}$, respectively. The hydraulic retention time (HRT) and sludge retention time (SRT, sludge age) were maintained at a level of 43 hours and 20 days, respectively. During the investigated operational time the mixed liquor suspended solids (MLSS) concentration was $5.8 \mathrm{~kg} / \mathrm{m}^{3}$. The sludge volume index (SVI) value of $82 \mathrm{~cm}^{3} / \mathrm{g}$ indicates good settling characteristics of the activated sludge. The concentration of dissolved oxygen in aerobic chamber was $3.2 \pm 1.8 \mathrm{mg} \mathrm{O}_{2} / \mathrm{L}$. As the operators of the WWTP under study claimed the nitrification failures in the winter time the comparative analysis of different operational parameters was done in relation to the nitrification efficiency. As the temperature has a great influence on the nitrification process the batch tests were also performed.

\section{Temperature sensitivity of activated sludge - long and short term tests}

In order to specify the impact of temperature on activated sludge from the WWTP of interest two kinds of tests were performed: short and long term tests. Both tests can be classified as Ammonia Utilization Rate (AUR) tests. The tests were performed on nitrifying activated sludge taken from the above-mentioned industrial WWTP (SRT amounted to approx. 20 days).

The short term tests were done in order to assess the acute effect of temperature on nitrification efficiency. Four batch tests were performed in one litre fully mixed and continuously aerated reactors that were seeded with $500 \mathrm{ml}$ of activated sludge and $500 \mathrm{ml}$ of wastewater, both taken from the WWTP under study. The ammonium load was equal to $0.015 \mathrm{~g} \mathrm{NH}_{4}-\mathrm{N}$ per day and $\mathrm{g}$ of dry mass of activated sludge. The reactors were incubated for 24 hours at the following temperatures: 13 , 16,19 and $22^{\circ} \mathrm{C}$. The temperature range was established basing on the temperature range the WWTP operates during a year. The wastewater from the reactor was sampled in $0.5,1.0,2.0$, 3.0, 4.0, 6.0 and 24.0 hour of the experiment, but only the first and last sample was taken into account in the discussion panel. The concentration of $\mathrm{NH}_{4}^{+}-\mathrm{N}$ was determined in the filtered samples.

The long term test relied on wastewater treatment with consequtive decrease of temperature every 5 days in the steps of: $22,19,16,13$ and $10^{\circ} \mathrm{C}$. It was performed on completely mixed activated sludge reactor seed with activated sludge from WWTP under study and real wastewater taken from the same WWTP. The reactor was continuously aerated. The HRT and SRT were maintained closer to the values of WWTP. Nitrogen forms were monitored in effluent and effluent of the reactor.

\section{Toxicity tests}

For the assessment of the wastewater toxicity influence on activated sludge biocenosis two types of tests were used: OUR (Oxygen Uptake Rate) test and Vicia faba micronucleus test (MCN). The OUR test reveals the acute toxicity of wastewater to activated sludge microorganisms while the MCN test indicates the mutagenotoxicity.

\section{OUR}

The toxic properties of the industrial wastewater were evaluated on 24-hour starvation of activated sludge taken from the WWTP under study. The sludge was then centrifuged and washed with water to remove all the substrates and metabolites. OUR was performed in $100 \mathrm{ml}$, tightly closed vessel equipped with $\mathrm{O}_{2}$-electrode at room temperature. The sludge was aerated to the full saturation, i.e. $8.5 \mathrm{mg} \mathrm{O}_{2} / 1$. The OUR was expressed as $\mathrm{mg}$ of oxygen used by $\mathrm{g}$ of biomass per hour. The experiment was divided into 10 steps. In every step, OUR was measured in two pairs: for the activated sludge and portion of water (reference, $\mathrm{OUR}_{\mathrm{R}}$ ) and secondly for the activated sludge and portion of the wastewater $\left(\mathrm{OUR}_{\mathrm{ww}}\right)$. The volume of water and wastewater portion was the same in each step. The proportions between activated sludge and wastewater (water) volume in steps 1-10 were: 0.02, 0.04, 0.06, 0.08, $0.10,0.16,0.25,0.49,1.0$ and 4.0 , respectively. The negative or positive value of the difference between $\mathrm{OUR}_{\mathrm{wW}}$ and $\mathrm{OUR}_{\mathrm{R}}$ was the indicator of inhibitory or stimulatory character of wastewater.

Table 1. Parameters of the raw wastewater

\begin{tabular}{|l|c|c|c|c|c|}
\hline Parameter & Unit & $\begin{array}{c}\text { Number } \\
\text { of measurements }\end{array}$ & Range & Average & Median \\
\hline $\mathrm{COD}$ & $\mathrm{mg} / \mathrm{L}$ & 357 & $736-2489$ & $1566 \pm 217$ & 1558 \\
\hline $\mathrm{NH}_{4}-\mathrm{N}$ & $\mathrm{mg} / \mathrm{L}$ & 358 & $18-303$ & $153.8 \pm 33.7$ & 147.5 \\
\hline $\mathrm{CH}_{4} \mathrm{~N}_{2} \mathrm{O}$ (urea) & $\mathrm{mg} / \mathrm{L}$ & 356 & $7-599$ & $52 \pm 66$ & 30 \\
\hline $\mathrm{NO}_{3}-\mathrm{N}$ & $\mathrm{mg} / \mathrm{L}$ & 355 & $0-63.2$ & $6.4 \pm 8.2$ & 3.3 \\
\hline $\mathrm{PO}_{4}-\mathrm{P}$ & $\mathrm{mg} / \mathrm{L}$ & 343 & $0.2-50$ & $7.3 \pm 4.1$ & 6.8 \\
\hline $\mathrm{SS}$ & $\mathrm{mg} / \mathrm{L}$ & 354 & $0-444$ & $86 \pm 64$ & 67 \\
\hline
\end{tabular}


Vicia faba micronucleus assay (MCN)

- root tip preparations and treatment

The protocol published by (Cotelle et al. 1999) was adapted for Vicia faba seeds (Cultivar: Windsor White). The dry seeds were soaked in distilled water for 24-h and then allowed to germinate on moist gauze for 3 days at $25^{\circ} \mathrm{C}$. Primary roots, length $1.00-2.00 \mathrm{~cm}$, were used in the test. Root tips were exposed for $24 \mathrm{~h}$ to $5 \%, 10 \%, 30 \%, 60 \%$ and $100 \%$ solutions of the influent and effluent from the WWTP. Plants were cultivated in a controlled chamber under neon lamps irradiance (Daylight, PILA). Chlorine free tap water was used as a negative control during the experiment. As a positive control maleic hydrazide at the concentration of $0.448 \mathrm{~g} / \mathrm{L}$ (Acros Organics) was used. Each experimental group was stored at $24 \pm 2^{\circ} \mathrm{C}$. After staining the root tips with $1 \%$ aceto-orcein, the interphase cells were scored for micronucleus frequencies at $1000 \times$ magnification. The MN frequency was defined as a number of cells with micronuclei MN per 1000 cells scored, resulting from 5000-7000 examined for each treatment (wastewater concentration). Results are presented as mean \pm standard deviation and the statistical significance of the differences between the control and treated groups means were determined using the one way method: ANOVA test and Microsoft ${ }^{\mathrm{TM}}$ Excel Statistic ToolPack $(\mathrm{p}<0.05)$.

\section{Activated sludge analysis}

Activated sludge samples were fixed with a paraformaldehyde solution (4\% paraformaldehyde in phosphate-buffered saline, PBS, pH 7.2) at $4^{\circ} \mathrm{C}$ for 3 hours and subsequently washed in PBS. Fixed samples were stored in PBS: ethanol (1:1) solution at $20^{\circ} \mathrm{C}$. In situ hybridization was performed as described previously by Daims et al. (2005). For the identification of ammonia-oxidizing bacteria (AOB) the following probes were chosen: NEU - targeting most halophilic and halotolerant Nitrosomonas sp. (Wagner et al. 1995), Cluster6a192 - for Nitrosomonas oligotropha lineage (Adamczyk et al. 2003), Ncmob - Nitrosococcus mobilis lineage (Juretschko et al. 1998), Nsv443 - targeting Nitrosospira sp. (Mobarry et al. 1996) and Ncom1025 for Nitrosomonas communis (Anneser 2004). In order to identify the nitrite-oxidizing bacteria, the probes NIT3 - for Nitrobacter sp. (Wagner et al. 1995), Ntspa662 - for Nitrospira sp. (Daims et al. 2001) were used. Details on the selected oligonucleotide probes (target sides and formamid concentration) are available at probeBase (Loy et al.
2007, Greuter et al. 2016). For detection of all bacteria mixture of probes EUB338, EUB338 II and EUB338 III were used in the proportion 1:1:1. The probes were 5' labelled with the dye FLUOS (5(6)-carboxyfluorescein-N-hydroxysuccinimide ester) or $\mathrm{Cy} 3$. Both the probes and unlabeled competitor oligonucleotides were obtained from Biomers, Ulm, Germany. Prior to microscope observations the samples were embedded in Citifluor (Citifluor Ltd, UK) to reduce fluorochrome fading and an epifluorescence microscope (MOTIC BA400T).

\section{Results and discussion}

\section{Temperature influence on nitrification}

Since the primary treated wastewater is retained in equalizing tank the temperature of wastewater discharged to the secondary treatment stage is strongly dependent on the air temperature. During the 2.5 year of interest the temperatures of wastewater varied in the range of $10-28^{\circ} \mathrm{C}$. The coldest months were January, February and March. During the time the COD and $\mathrm{P}$ removal was stable, varying in the range of $72-94 \%$ and $66-99 \%$, respectively. The nitrogen removal was changeable during the years and varied between 0 and $98 \%$. The average removals obtained in different months are presented in Figure 1.

A detailed analysis of the results revealed the strong negative temperature impact on nitrification process. A relatively strong correlation (Pearson coefficient of 0.71 ) between temperature of the mixed liquor in the reactor and the ammonium concentrations in the effluent obtained in this case for full scale treatment is of great importance. The dependence of biological processes on temperature is well known, however, the reported analyses of the temperature influence on the effluent concentration of municipal WWTP do not usually reveal such a noticeable effect for data collected in a long term (Popel and Kristeller 1996) and often the cause of nitrification breakdown is difficult to determine (Ghyoot and Verstraete 1999, 2000, Nagaoka 1999). The nitrification process could be affected by different agents (e.g. DO concentration, load irregularity) but the strongest correlation in this case was obtained for temperature.

Interrelation between temperature and microbial growth rate $(\mu)$ is usually described with an exponential equation that links the minimal SRT (inversion of activated sludge microbial growth rate), ensuring sufficient amount of nitrifying bacteria

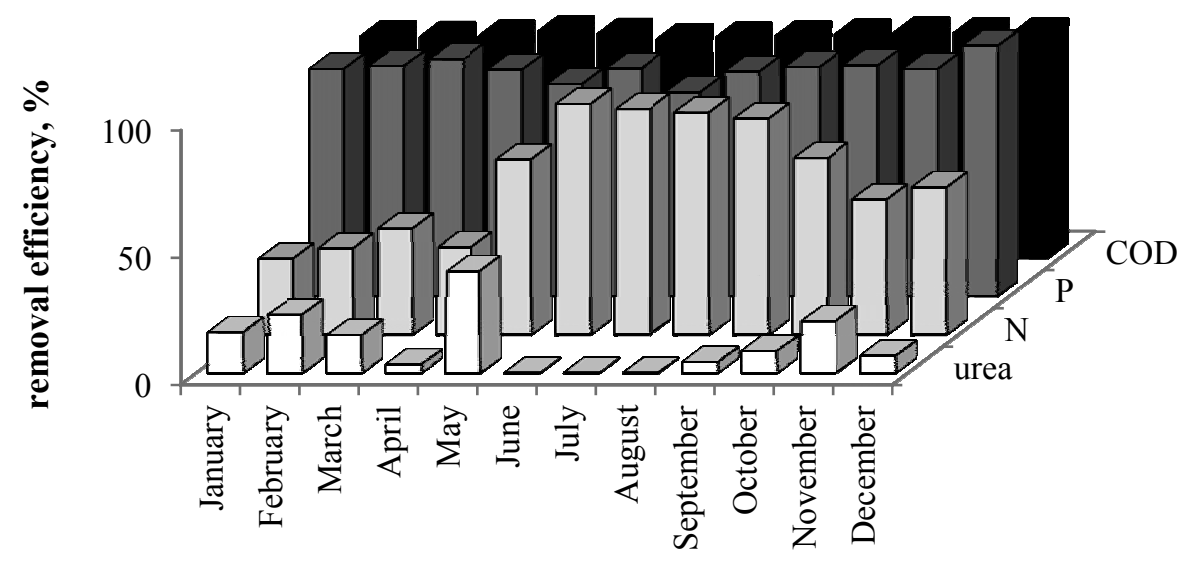

Fig. 1. COD, urea, $N$ and $P$ removal during biological treatment of chemical wastewater 
with a temperature of the process (Popel and Fischer 1998). In order to solve the equation the following assumptions were made: 1) minimal sludge age $\left(\mathrm{SRT}_{\min }\right)$ is calculated as an average sludge age obtained in the period of the nitrification breakdown and nitrification recovery correlated with the average temperature in the investigated periods, 2) to assess the influence of temperature on $\mathrm{SRT}_{\text {min }}$ the temperature coefficient recommended by ATV guidelines for municipal wastewater was used. The above mentioned equation was solved and it can be written as (1):

$$
S T R_{\min }=31.8 \times 1.103^{(15-T)}
$$

where:

$S R T_{\min }-$ minimal SRT for stable nitrification, $\mathrm{d}$

$\mathrm{T}$ - temperature, ${ }^{\circ} \mathrm{C}$.

Figure 2 presents the information on ammonia concentrations in the treated industrial wastewater in juxtaposition of minimal and real sludge age.

In the light of the obtained results presented in the Figure 2 it becomes obvious that the nitrification is strongly inhibited while the sludge age is lower than minimal. The periods of nitrification failure were characterized by average temperature of $17^{\circ} \mathrm{C}$. However, in the over 2 years' period of interest the temperature was lower than $10^{\circ} \mathrm{C}$ twice, but the duration exceeded 7 days. According to the obtained data and equation (1), it was calculated that in order to provide the stable nitrification, in winter period the sludge age (SRT) in the WWTP should be higher than 35 days.

In order to confirm the obtained observations the short-term batch tests were performed. The aim of the tests was to experimentally assess the lowest temperature needed for an acceptable nitrification. In the experiments carried out for 24 hours the obtained results show acute response of the nitrifiers activity to temperature expressed by means of Ammonia Utilization Rate (AUR) tests (Figure 3). The presented results are in concordance with the previously reported results. Temperature lower than $16^{\circ} \mathrm{C}$ caused significant decrease of ammonia oxidation - the nitrification process capacity is reduced by approx. $46 \%$ compared to the efficiency of the process which is observed at a temperature of $22^{\circ} \mathrm{C}$. When the temperature fell to $13^{\circ} \mathrm{C}$ the nitrification efficiency was reduced by $72 \%$.

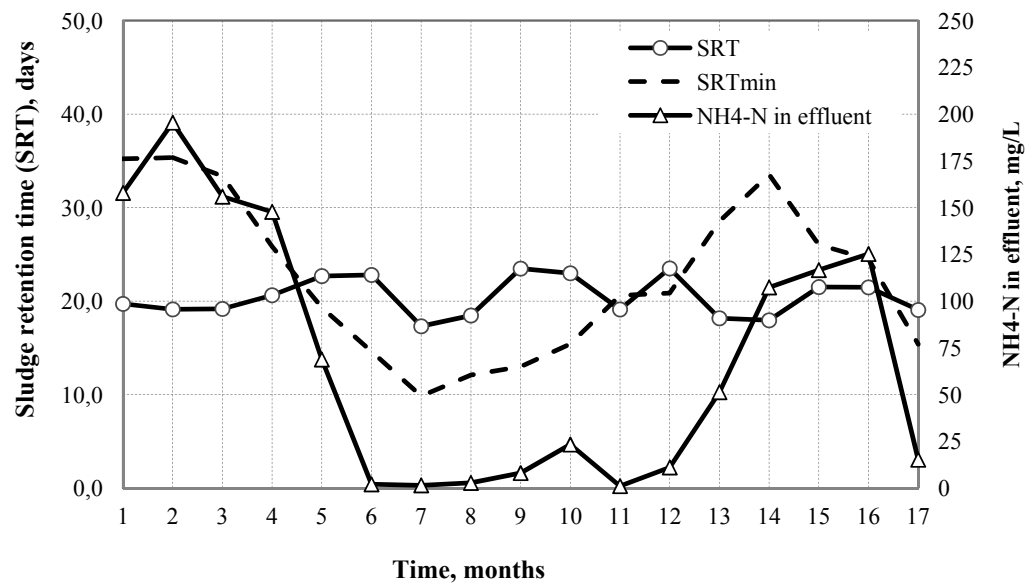

Fig. 2. Changeability of ammonia concentration in the effluent from industrial WWTP in juxtaposition of minimal and real sludge age (months $1-3$ and 13-15 - winter period; months 4-6 and 16-17 - spring period; months 7-9 - summer period; months 10-12 - autumn period)

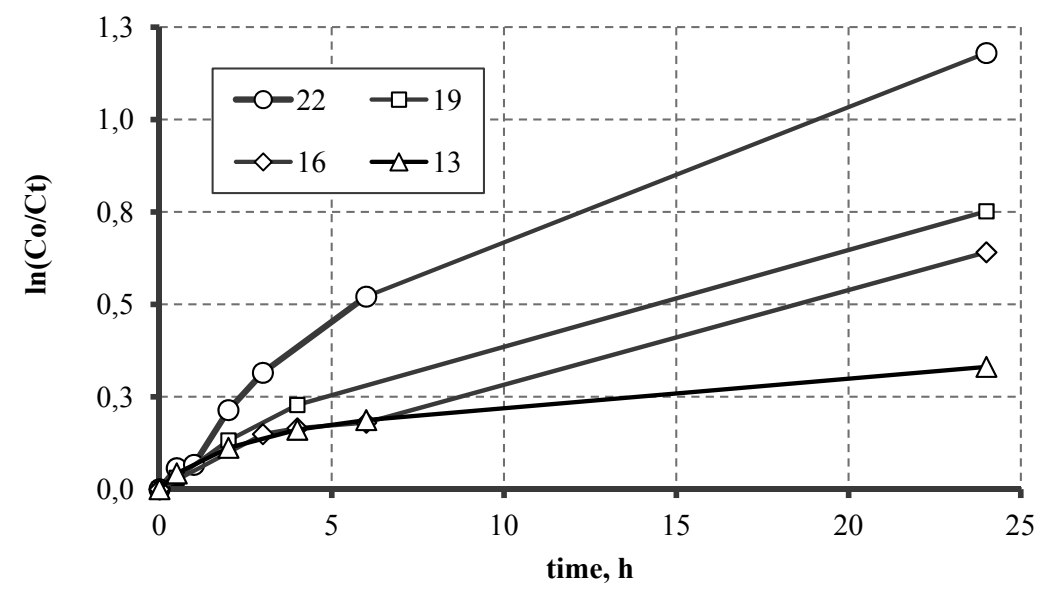

Fig. 3. Ammonia Utilization Rate (AUR) tests performed during short-term experiments at various temperatures of the treatment $\left(\mathrm{C}_{0}-\mathrm{NH}_{4}-\mathrm{N}\right.$ initial concentration; $\mathrm{C}_{\mathrm{t}}-\mathrm{NH}_{4}-\mathrm{N}$ concentration after $\mathrm{t} ; \mathrm{t}-$ time of the process $)$ 
Following this tendency, the temperature of $10^{\circ} \mathrm{C}$ should result in total nitrification inhibition (Figure 4).

Nitrification of municipal wastewater is known to be inhibited in temperature lower than $11^{\circ} \mathrm{C}$ and completely inhibited below $5^{\circ} \mathrm{C}$ (Hagopian and Relay 1998,Kishino et al. 1996). Some researchers (Sudarma et al. 2011) report nitritation of landfill leachate total collapse at $6^{\circ} \mathrm{C}$. Moreover, the nitratation at $6^{\circ} \mathrm{C}$ was observable but very low. However, during complete nitrification performance the nitratation depends on nitrite produced in nitritation so the disturbances in the first phase of nitrification affect the whole nitrification process. The results are in agreement with the insights of Guo et al. (2010) during research on partial nitrification of domestic wastewater. They found that the decreasing temperature affected ammonia oxidation rate but not the nitrite accumulation ratio. Hoilijokki et al. (2000) conclude the results of their research by saying that wiling to obtain nitrification at low temperatures the carrier reactors are beneficial.There are several reports where nitrification was obtained at $10^{\circ} \mathrm{C}$ in carrier reactor (Jokela et al.2002, Isaka et al. 2007), but only in one example (Isakaet al. 2007) the nitrification rate was acceptable for technical scale.

The industrial character of the wastewater under study influences the activated sludge microorganisms resulting in a higher vulnerability to temperature in comparison to the municipal activated sludge microorganisms. Higher sensitivity of activated sludge to temperature during exposition to toxic wastewater was shown by Redey et al. (2011). In this case study, the domestic wastewater treatment plant was occasionally set up in wastewater from pharmaceutical factory. Normally, the nitrification was stable and satisfactory at $17^{\circ} \mathrm{C}$ (winter conditions) but when toxic substances coupled with lower temperature impacted, nitrification efficiency felt drastically, and the system could not restore itself. Pambrun et al. (2008) showed that different toxicants may have different impact on the activated sludge activity at low temperature. Moreover, deteriorative effect of some known toxicants may not be enhanced by lowering the temperature. In order to confirm the presented thesis, the wastewater impact on activated sludge biocenosis was investigated on a basis of toxicity tests, the results of which are shown below.

\section{Industrial wastewater toxicity}

The OUR test shows stimulating character of the industrial wastewater on activated sludge. Each time the measured OUR was significantly higher for the samples with wastewater than for the reference sample. Figure 5 shows the difference between $\mathrm{OUR}_{\mathrm{ww}}$ and $\mathrm{OUR}_{\mathrm{R}}$.

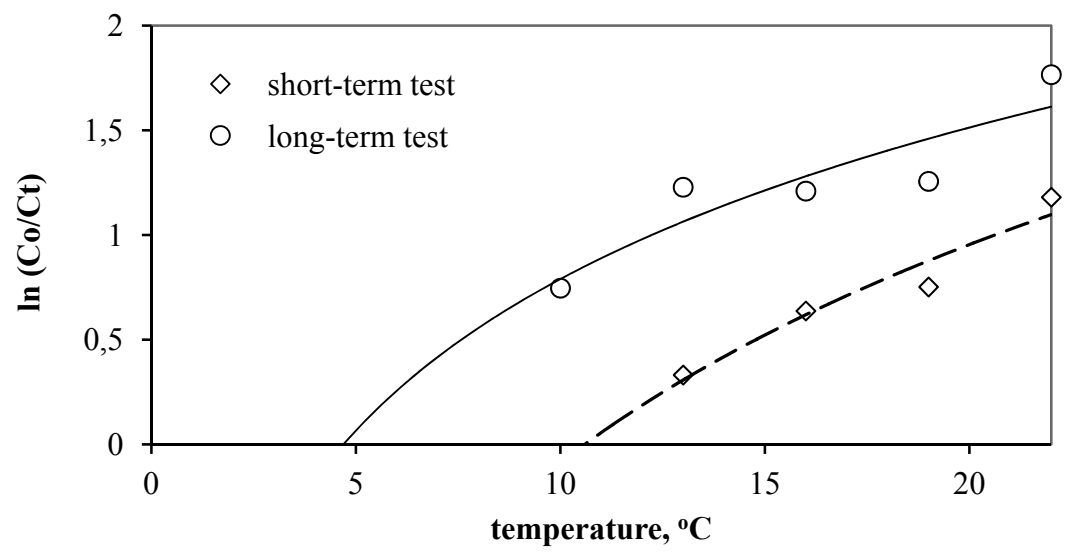

Fig. 4. Relation between treatment process temperature and $\mathrm{NH} 4-\mathrm{N}$ removal efficiency after 1 day of the process (in the short-term tests) and 5 days of the process (in the long-term tests) $\left(\mathrm{C}_{0}-\mathrm{NH}_{4}-\mathrm{N}\right.$ initial concentration; $\mathrm{C}_{\mathrm{t}}-\mathrm{NH}_{4}-\mathrm{N}$ concentration after respectively 1 day and 5 days of the process)

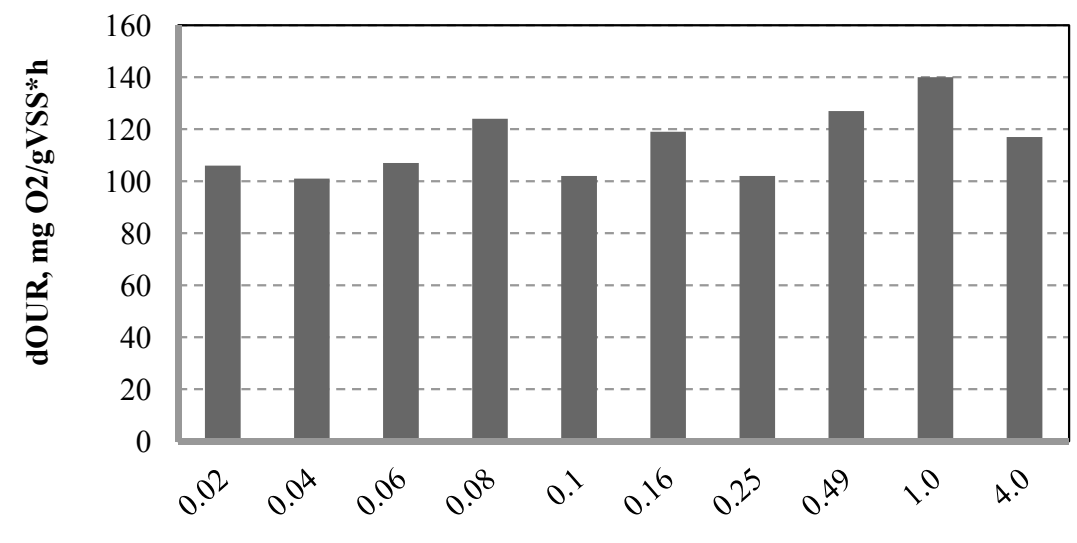

Wastewater : activated sludge $\mathrm{ratio}, \mathrm{ml} / \mathrm{ml}$

Fig. 5. Influence of wastewater on activated sludge activity 
The supply of substrate content in wastewater caused increase of microbial activity which was not correlated with substrate concentration. The increase of the substrate concentration did not affect negatively the microorganisms. The investigated ratios were much higher than the loads the microorganisms are adapted to. This experiment indicates that the wastewater does not have acute toxic character on the activated sludge biocenosis.

The $V$. faba micronucleus test showed that the raw wastewater was significantly genotoxic (at the concentration of 60 and $100 \%$ ) as compared with the tap water used as the negative control (Table 2). However, the wastewater taken in winter period induced considerably stronger genetic damage towards $V$. faba cells than the wastewater collected in late spring season; micronuclei frequency produced by the wastewater taken in winter period is not significantly different from the positive control, which is a potent, well-known mutagenic/clastogenic agent in plant system (Grant 1994, El Hajjouji et al. 2007).

For wastewater collected in late spring season, the MCN was always statistically different from positive control. The results imply a seasonal difference in genotoxicity induced by wastewater.
MCN assays proved to be a reproducible and sensitive indicator of exposure for mutagenic risk. MCN frequencies significantly increased with increasing concentrations of untreated wastewater and the concentration-response curve fitted well with the following equations: $y=0.109 x+0.088$ $\left(\mathrm{r}^{2}=0.90\right)$, for the wastewater taken in winter period and $y=0.060 x+0.654\left(r^{2}=0.999\right)$, for the wastewater collected in late spring season.

The presented data do not prove that the nitrifying population decay was a result of wastewater composition, but it may be expected that wastewater taken in winter period contained some antimicrobial agents, which cannot be ascertained by means of general parameters such as COD, $\mathrm{BOD}_{5}$, etc. The presence of xenobiotics and their primary degradation products in the influents of WWTPs may inhibit irreversibly sensitive biological processes, such as nitrification (Dokianakis et al. 2006).

\section{Activated sludge biocenosis}

The activated sludge biocenosis was investigated in two periods: during acceptable nitrification efficiency (late spring time) and nitrification breakdown (winter time). The results are presented in Table 3.

Table 2. Micronucleus frequency values in Vicia faba root tips exposed within $24 \mathrm{~h}$ to wastewater collected in winter period and late spring period

\begin{tabular}{|c|c|c|c|c|}
\hline \multirow{2}{*}{\multicolumn{2}{|c|}{$\begin{array}{c}\text { Treatment /concentration,\% } \\
\text { Negative control }\end{array}$}} & \multicolumn{2}{|c|}{ 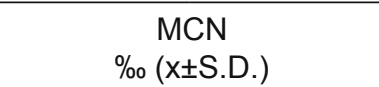 } & \multirow[t]{2}{*}{ Significance } \\
\hline & & 1.30 & 0.70 & \\
\hline \multicolumn{2}{|c|}{ Positive control } & 13.17 & 1.17 & \\
\hline \multirow{5}{*}{$\begin{array}{l}\text { Wastewater, } \\
\text { winter period }\end{array}$} & $100, \%$ & 12.20 & 2.16 & * \\
\hline & $60, \%$ & 5.17 & 0.89 & $* /+$ \\
\hline & $30, \%$ & 2.17 & 0.89 & $* /+$ \\
\hline & $10, \%$ & 0.80 & 0.64 & + \\
\hline & $5, \%$ & 2.50 & 1.00 & + \\
\hline \multirow{5}{*}{$\begin{array}{l}\text { Wastewater, } \\
\text { spring period }\end{array}$} & $100, \%$ & 6.67 & 0.78 & * \\
\hline & $60, \%$ & 4.33 & 0.44 & $* /+$ \\
\hline & $30, \%$ & 2.50 & 0.50 & $* /+$ \\
\hline & $10, \%$ & 1.17 & 1.22 & + \\
\hline & $5, \%$ & 1.00 & 0.67 & + \\
\hline
\end{tabular}

Significant difference between negative $\left(^{*}\right)$ and/or positive control $(+), p<0,05$

Table 3. Detection of nitrifying bacteria in activated sludge (+ present, - not present)

\begin{tabular}{|c|c|c|c|}
\hline \multirow{2}{*}{ Target organism } & \multirow{2}{*}{ Probe name } & \multicolumn{2}{|c|}{ Experiment time } \\
\hline & & winter & spring \\
\hline $\begin{array}{l}\text { AOB (ammonia oxidizing bacteria) } \\
\text { Nitrosomonas oligotropha lineage }\end{array}$ & $\mathrm{Cl} 6 \mathrm{a}$ & + & + \\
\hline Nitrosospira spp. & Nsv443 & + & + \\
\hline most halophilic and halotolerant Nitrosomonas spp. & NEU & + & + \\
\hline Nitrosococcus mobilis ("Nitrosomonas") lineage & Ncmob & + & - \\
\hline \multicolumn{4}{|l|}{ NOB (nitrite oxidizing bacteria) } \\
\hline Nitrobacter spp. & NIT3 & - & + \\
\hline genus Nitrospira & Ntspa & + & + \\
\hline
\end{tabular}


The bacterial diversity was slightly different in the periods when nitrification exhibited high (spring) and low (winter) efficiency. Among NOB bacteria a lack of Nitrobacter sp. was ascertained in winter time. Unfortunately the data on nitrite concentration are not available, but it is possible that the second nitrification stage can be inhibited by a particular wastewater agent that resulted in nitrite accumulation and consequently inhibition of AOB. However, due to lack of the data on the nitrite concentration in the effluent this hypothesis cannot be confirmed. The activated sludge composition has the most important impact on removal efficiency as the activated sludge bacteria are the heart of wastewater treatment. Thus it is worth to mention the observations of Cho et al. (2014). They report that even at optimal temperature conditions (also $\mathrm{pH}$ ) the differences in nitrification efficiencies result from differences in proportions of nitrifying bacteria among total bacteria. Moreover, changes in ammonia oxidizing bacteria community being a consequence of increase of salinity and temperature and reduction of DO content were responsible for a perturbation on nitrification during summer times reported by Beneduce et al. (2014).

\section{Conclusions}

Temperature was found to be crucial parameter for nitrification of fertilizer wastewater. The data collected during almost 3 years of the WWTP operation showed that during winter time the sludge age should be maintained at the level of at least 35 days. The WWTP operation in the winter time at the lower sludge age results in the decrease of nitrification efficiency. The activated sludge was sensitive to the temperature decline. Under $16^{\circ} \mathrm{C}$ the nitrification efficiency decreased and presumably at $10^{\circ} \mathrm{C}$ the nitrification would be inhibited completely. The raw wastewater taken in winter period has greater genotoxicity potential than the wastewater collected in late spring season. This indicates an important fluctuation (seasonal differences) of mutagenic compounds among the different periods of the chemical factory operation. The microscopic analysis revealed appreciable changes in biodiversity of nitrifying bacteria group, especially in the nitrite oxidizing bacteria.

\section{References}

Adamczyk, J., Hesselsoe, M., Iversen, N., Horn, M., Lehner, A., Nielsen, P.H., Schloter, M., Roslev, P. \& Wagner, M. (2003). The isotope array, a new tool that employs substrate-mediated labeling of rRNA for determination of microbial community structure and function, Applied and Environmental Microbiology, 69, pp. 6875-6887.

Anneser, B. (2004). Biodiversity and ecophysiology of nitrifying bacteria in wastewater treatment plants. Diploma thesis, Technical University of Munich, Germany. (in German)

Anthonisen, A.C., Loehr, R.C., Prakasam, T.\& Stinath, E.G. (1976). Inhibition of nitrification by ammonia and nitric acids, Journal of the Water Pollution Control Federation, 48, pp. 835-852.

Cotelle, S., Masfaraud, J.F. \& Ferard, J.F. (1999). Assessment of the genotoxicity of contaminated soil with the Allium/Vicia micronucleus and the Tradescantia-micronucleus assays, Mutation Research, 426, pp. 167-171.

Daims, H., Stoecker, K. \& Wagner, M. (2005). Fluorescence in situ hybridization for the detection of procaryotes, in: Advanced methods in molecular microbial ecology, Osborn, A.M., Smith, C.J. (Eds.), Bios-Garland, Abingdon, UK, pp. 213-239.

Daims, H., Nielsen, P.H., Nielsen, P.H., Schleifer, K.H. \& Wagner, M. (2001). In situ characterization of Nitrospira-like nitrite oxidizing bacteria active in wastewater treatment plants, Applied and Environmental Microbiology, 67(11), pp. 5271-5284.

Dokianakis, S.N., Kornaros, M. \& Lyberatos, G. (2006). Impact of five selected xenobiotics on isolated ammonium oxidizers and on nitrifying activated sludge, Environmental Toxicology, 21 (4), pp. 310-316.

El Hajjouji, H., Pinelli, E., Guiresse, M., Merlin,a G., Revel, J.-C. \& Hafidi, M. (2007). Assessment of the genotoxicity of olive mill waste water (OMWW) with the Vicia faba micronucleus test, Mutation Research, 634, pp. 25-31.

Ghyoot, W. \& Verstraete, W. (2000). Reduced sludge production in a two-stage membrane-assisted bioreactor, Water Research, 34(1), pp. 205-215.

Ghyoot, W. \& Verstraete, W. (1999). Nitrogen removal from sludge reject water with a membrane - assisted bioreactor, Water Research, 33(1), pp. 23-32.

Grant, W. (1994). The present status of higher plant bioassay for the detection of environmental mutagens, Mutation Research, 310, pp.175-185.

Greuter, D., Loy, A., Horn, M. \& Rattei, T. (2016). ProbeBase - an online resource for rRNA-targeted oligonucleotide probes and primers: new features 2016, Nucleic Acids Research 10.1093/nar/gkv1232.

Wen, J., Jia, X., Pan, L., Wang C. \& Mao, G. (2005). Nitrifying treatment of wastewater from fertilizer production in a multiple airlift loop bioreactor, Biochemical Engineering Journal, 25, pp. 33-37.

Juretschko, S., Timmermann, G., Schmid, M., Schleifer, K.H., Pommerening-Roser, A. \& Wagner, M. (1998). Combined molecular and conventional analyses of nitrifying bacterium diversity in activated sludge: Nitrosococcus mobilis and Nitrospira-like bacteria as dominant populations, Applied and Environmental Microbiology, 64, 3042-3051.

Hagopian, D.S. \& Riley, J. (1998). A closer look at the bacteriology of nitrification, Aquacultural Engineering, 18, pp. 223-244.

Henglong, X., Weibo, S. \& Alan, W. (2004). An investigation on the tolerance to ammonia of the marine ciliate Euplotes vannus (Protozoa, Ciliphora), Hydrobiologia, 519(1-3), pp. 189-195.

Kishino, H., Ishida, H., Iwabu, H. \& Nakano, I. (1996). Domestic wastewaters reuse using a submerged membrane bioreactor, Desalination, 106, pp. 115-119.

Mobarry, B.K., Wagner, M., Urbain, V., Rittmann, B.E. \& Stahl, D.A. (1996). Phylogenetic probes for analyzing abundance and spatial organization of nitrifying bacteria, Applied and Environmental Microbiology, 62, pp. 2156-2162.

Nagaoka, H. (1999). Nitrogen removal by submerged membrane separation activated sludge process, Water, Science and Technology, 39(8), pp. 107-114.

OSPAR Commission, 2002: Survey on Genotoxicity Test Methods for the Evaluation of Waste Water within Whole Effluent Assessment, ISBN 1-904426-02-6.

Popel, H.J. \& Fischer, A. (1998). Combined influence of temperature and process loading in the effluent concentration of biological treatment, Water Science and Technology, 38(8-9), pp. 129-136.

Popel, H.J. \& Kristeller, W. (1996). Post-denitrification at the Frankfurt-Niederrad wastewater treatment plant by fluidizedbed technology, in: Advanced Wastewater Treatment - nutrient removal and anaerobic processes - IAWQ-NVA-Conference, September 23-25, Amsterdam, pp. 153-162.

Puigagut, J., Salvado H. \& Garcia, J. (2005). Short-term harmful effects of ammonia nitrogen on activated sludge microfauna, Water Research, 39, pp. 4397-4404. 
Ukropec, R., Kuster, B.F.M., Schouten, J.C. \& van Santen, R.A. (1999). Low temperature oxidation of ammonia to nitrogen in liquid phase, Applied Catalysis B: Environmental, 23, pp. 45-57.
Wagner, M., Rath, G., Amann, R., Koops H.-P. \& Schleifer, K.-H. (1995). In situ identification of ammonia-oxidizing bacteria, Systematic and Applied Microbiology, 18, pp. 251-264.

\title{
Wpływ ścieków przemysłowych na wrażliwość temperaturową procesu nitryfikacji
}

\begin{abstract}
Streszczenie: Badanie efektywności nitryfikacji przeprowadzono przy użyciu ścieków pochodzących z jednego $\mathrm{z}$ polskich przedsiębiorstw chemicznych, specjalizujących się w wytwarzaniu nawozów azotowych i różnych chemikaliów, jak przykładowo alkoholi OXO, klejów mocznikowych, estrów ftalowych (plastyfikatory) i bezwodnika maleinowego. Badane ścieki stanowiły dopływ do mechaniczno-biologicznej oczyszczalni ścieków, która zapewniała wysoką efektywność usunięcia związków organicznych definiowanych jako chemiczne zapotrzebowanie na tlen (ChZT), jednak nie gwarantowała ona zapewnienia odpowiedniego usunięcia związków azotowych, ze względu na okresowe zakłócenia procesu nitryfikacji. Celem badań było ustalenie przyczyn powtarzających się okresowo zakłóceń procesu nitryfikacji. W niniejszej pracy toksyczność ścieków przemysłowych badano za pomocą pomiaru zmian aktywności oddechowej osadu czynnego (OUR) oraz określono genotoksyczność ścieków stosując test mikrojądrowy (test MCN) przy zastosowaniu komórek korzenia Vicia faba. Badanie OUR wykazało, że powyższe ścieki nie wykazują toksyczności ostrej względem mikroorganizmów osadu czynnego, jednakże przeprowadzony test MCN wykazał, że ścieki wykazują działanie genotoksyczne i ich genotoksyczność jest większa w okresie zimowym w porównaniu z ich genotoksycznością w okresie wiosennym. Analiza parametrów związanych z eksploatacją oczyszczalni ścieków z okresu 3 lat oraz wyniki własnych badań laboratoryjnych (okresowych) wykazały, ze osad czynny z omawianej oczyszczalni ścieków jest bardzo wrażliwy na zmiany temperatury i wydajność nitryfikacji wyraźnie spada poniżej $16^{\circ} \mathrm{C}$. Na podstawie przeprowadzonych badań obliczono, że aby zapewnić stabilną nitryfikację w okresie zimowym wiek osadu czynnego powinien być wyższy niż 35 dni.
\end{abstract}

